Pao-Jen Ann

Taiwan Agricultural Research Institute, Taichung, Taiwan

Tun-Tschu Chang

Taiwan Forestry Research Institute, Taipei, Taiwan

Wen-Hsiung Ko

University of Hawaii at Manoa, Hilo, $\mathrm{HI}$

\title{
Phellinus noxius Brown Root Rot of Fruit and Ornamental Trees in Taiwan
}

In 1985, the third author (W. H. Ko) noticed unusually high mortality of some fruit trees in residential areas in southern Taiwan. Tree death appeared to be very sudden, because all the leaves had turned brown but had remained attached to the branches (Fig. 1). In 1987, numerous dying longan trees (Dimocarpus longan) were found in the mountain areas of central and southern Taiwan. Trees in the early stages of decline exhibited a brown discoloration of the wood on large roots (Fig. 2). A fastgrowing, basidiomycete-like fungus was subsequently isolated from diseased roots, and inoculation studies verified its pathogenicity. However, it was not possible to identify the pathogen at the time because fruiting bodies were not initially found on diseased trees in the field or in laboratory cultures, nor were clamp connections observed on hyphae.

In 1990, Ko found a young, thin, flat, brown basidiocarp with a white margin on an exposed root of a diseased longan tree. He then realized that what looked like dirty bark on the basal stems of some declining trees was in fact remnants of decomposed fruiting bodies of the pathogen (Fig. 3) and that fungal structures previously thought to be mycelial mats on sawdust medium were actually fruiting bodies (Fig. 4). Subsequently, the fungus was identified as Phellinus noxius (Corner) G. H. Cunn.

Soon after the report of brown root rot causing serious decline in longan (2), the $P$. noxius pathogen was found to be widespread and destructive on a number of tree species throughout Taiwan. Due to the seriousness of the problem, the Taiwan government created a Phellinus noxius Brown Root Rot Diagnosis and Control Information Center in 2000 to address public concern about the disease.

Dr. Ko's address is: Department of Plant and Environmental Protection Sciences, Beaumont Agricultural Research Center, University of Hawaii at Manoa, Hilo, HI 96720; E-mail: kowh@hawaii.edu

Publication no. D-2002-0524-01F

(C) 2002 The American Phytopathological Society

\section{History and Occurrence of the Disease Worldwide}

The fungus causing brown root disease of trees was first described in Singapore by Corner in 1932 as Fomes noxius (18) and reclassified by Cunningham in 1965 as Phellinus noxius (19). Corner speculated that the fungus was the cause of brown root rot of rubber trees and tea bushes. However, attempts to demonstrate pathogenicity of this fungus were not successful until the realization that it requires a food base for successful infection of the host. Bolland (11) inoculated hoop pine (Araucaria cunninghamii) by inserting a severed root into a jar containing $250 \mathrm{~g}$ of enriched sawdust medium colonized by $P$. noxius. The fungus killed the inoculated root and began to girdle the tree within 6 months.

$P$. noxius has a wide host range; it has been reported on more than 200 plant species representing 59 families. Although most hosts are woody plants, some herba-

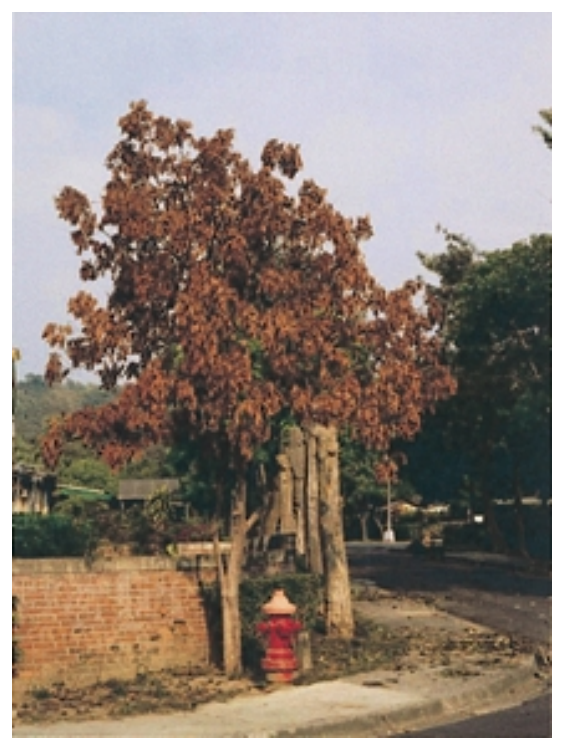

Fig. 1. Quick decline of a 6-year-old longan tree (Dimocarpus longan) resulting from brown root rot caused by Phellinus noxius. ceous plants are also susceptible to the pathogen. $P$. noxius is widespread among tropical countries in Southeast Asia, Africa, Oceania, Central America, and the Caribbean (25). It has also been reported from the tropical Hainan Island of China (29). In Japan, the pathogen was found only on the subtropical island of Okinawa (1). In Taiwan, it has been found in both tropical and subtropical districts $(8,17)$.

\section{The Pathogen}

$P$. noxius is a fast-growing organism. The linear growth rate can be $35 \mathrm{~mm} /$ day on potato dextrose agar (PDA) at $30^{\circ} \mathrm{C}$ $(4,7)$. The fungus produces a brown colony on PDA with irregular dark brown lines or patches permeating the culture (Fig. 5) Arthrospores (Fig. 6) and trichocysts (Fig. 7), but not clamp connections, are commonly produced in culture. When grown on sawdust medium, $P$. noxius produces thin, hard, uneven basidiocarps (Fig. 4) similar to those found in nature. They are initially yellowish-brown with a white margin and later become brown and then dark gray. In addition to basidiospores,

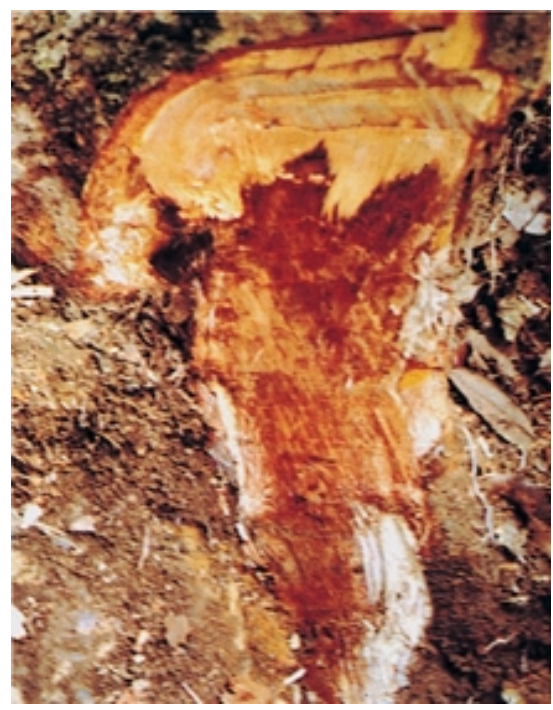

Fig. 2. A large longan root with brown discoloration caused by Phellinus noxius. 
there are scant hymenial setae and narrow setal hyphae inside the basidiocarp, which distinguish $P$. noxius from the closely related species of Phellinus lamaensis (Fomes lamaensis) (25).

$P$. noxius is a high-temperature organism with optimal growth near $30^{\circ} \mathrm{C}$ and none at $8^{\circ} \mathrm{C}$. This may explain the geographic restriction of this pathogen to tropical and subtropical regions. The fungus prefers acidic conditions and is capable of growth at a $\mathrm{pH}$ as low as 3.5. Growth is completely inhibited at a $\mathrm{pH}$ of 7.5 (7).

\section{Hosts and Geographic Distribution in Taiwan}

Brown root rot caused by $P$. noxius was reported in Taiwan by Sawada as early as 1928 (26). The fungus was identified as Fomes lamaensis, which he later considered to be a synonym of Fomes noxius (27). Initially, Sawada did not find the fruiting bodies of $P$. noxius, so the identification was based on the symptom of brown

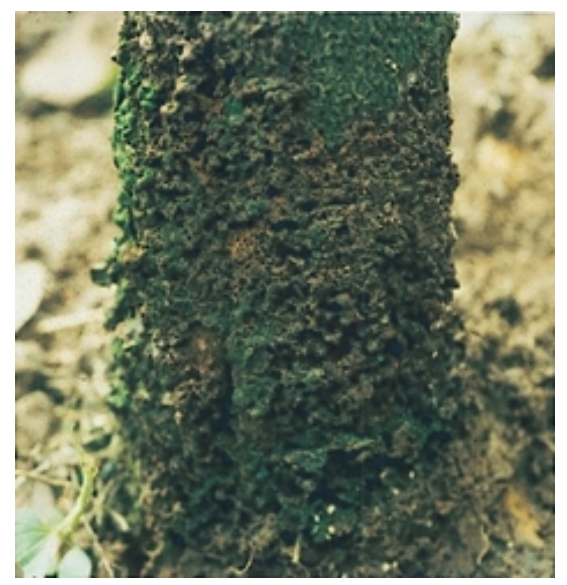

Fig. 3. Basal stem of a longan tree (Dimocarpus longan) with remnants of old decomposed fruiting bodies of Phellinus noxius.

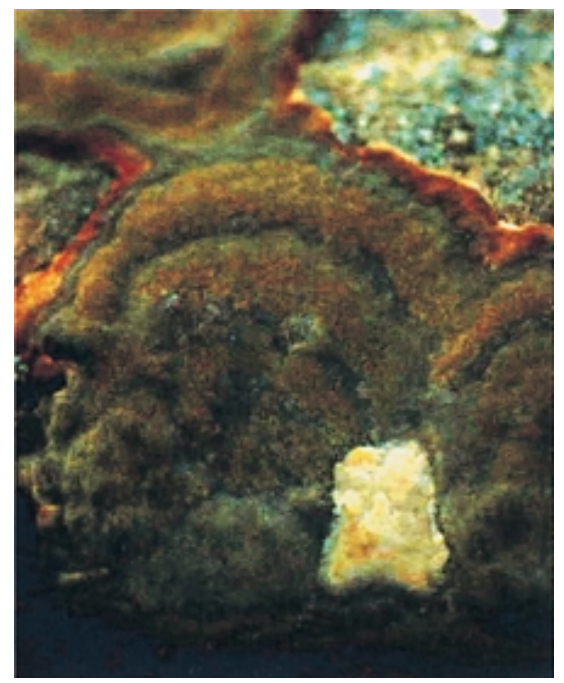

Fig. 4. A thin, flat basidiocarp of Phellinus noxius produced on sawdust medium. rot on roots. The 18 hosts (Table 1) he found were located in northern, central, and southern Taiwan. His report remained essentially unnoticed until 1991, when the fungus became a serious threat to the cultivation of certain fruit trees (2-4). Among the approximately 200 plant species listed as hosts of $P$. noxius in the world, about half of them were reported for the first time from Taiwan (Table 1). Most of the hosts found in Taiwan are woody fruit and ornamental trees. Only seven species are herbaceous plants.

Not all hosts listed in Table 1 have been proven experimentally to be susceptible to $P$. noxius. Prior to 1992, most species of plants were reported as hosts of $P$. noxius without completion of Koch's postulates. We employed a simple inoculation technique developed by Ko et al. (22) to demonstrate pathogenicity. The method consisted of culturing $P$. noxius in a wheatoat medium and wrapping approximately 5 $\mathrm{g}$ of the colonized medium with a sheet of clear plastic around the lightly scraped stem or taproot (4). Successful pathogenic-

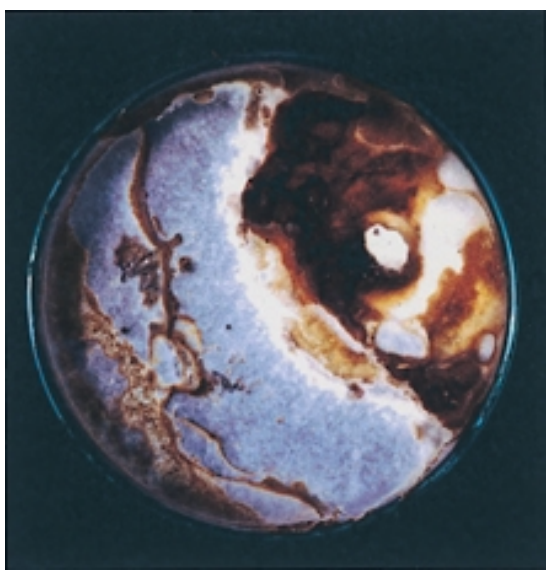

Fig. 5. Colony of Phellinus noxius on potato dextrose agar with irregular dark brown lines or patches permeating the culture.

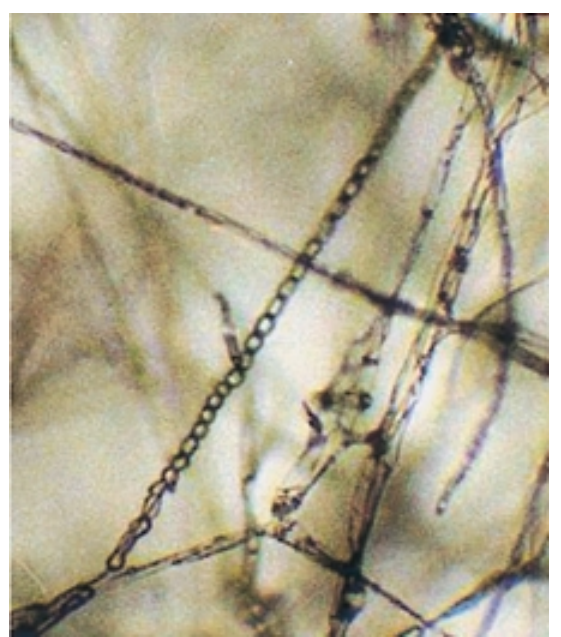

Fig. 6. Arthrospores of Phellinus noxius produced on potato dextrose agar. ity tests have now been accomplished with this method for most of the hosts of $P$. noxius reported from Taiwan $(4,7,9,13)$.

In Taiwan, $P$. noxius causes brown root rot on a number of popular tropical fruit crops such as longan, litchi, carambola, loquat, avocado, and sugar apple (Table 1). Some persimmon, peach, pear, plum, and grape cultivars were also attacked by the pathogen in subtropical areas. The disease causes considerable losses to growers each year. Due to its wide host range, most of the tree species used in ornamental landscape plantings are susceptible to brown root rot. $P$. noxius causes decline and death of ornamental trees planted on campuses, sightseeing places, and parks, and around private and public buildings (Figs. 8 and 9).

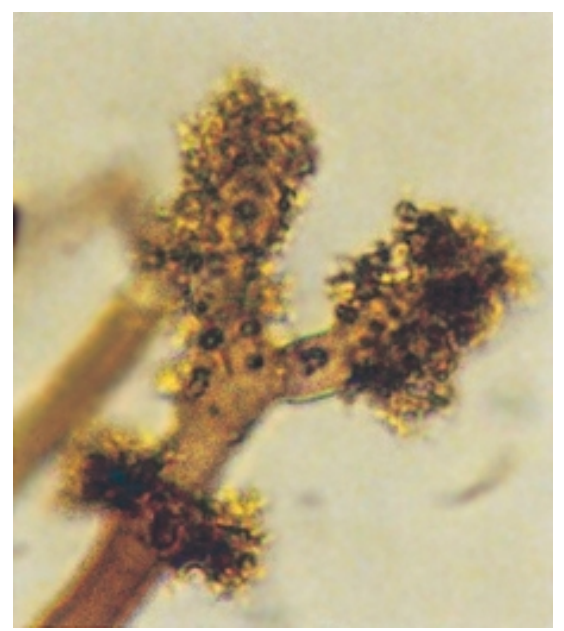

Fig. 7. Trichocysts of Phellinus noxius produced on potato dextrose agar.

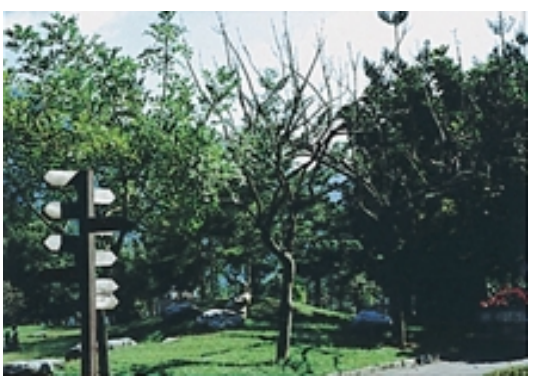

Fig. 8. A 5-year-old golden shower tree (Cassia fistula) killed by Phellinus noxius in a park.

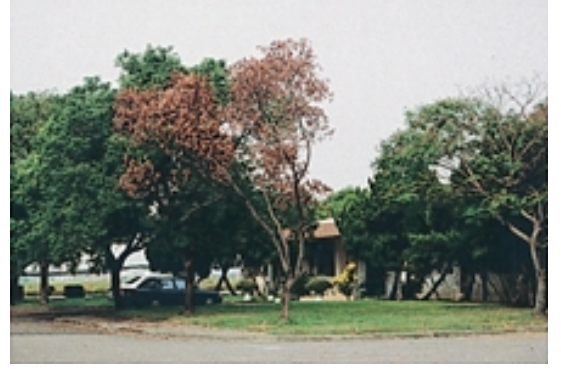

Fig. 9. A camphor tree (Cinnamomum camphor) killed by Phellinus noxius in front of a residential house. 
Brown root rot has been found in every county on the island of Taiwan (Fig. 10) but not in mountainous areas above 1,000$\mathrm{m}$ elevation, even though there are numerous susceptible hosts in those areas (17). Apparently the cold winter in these areas is detrimental to disease development (7).

The distribution of $P$. noxius in Taiwan appears to be limited to areas with human activity. Brown root rot has never been found in undisturbed natural forests, suggesting that the pathogen is not indigenous to Taiwan. Since the late nineteenth century, numerous fruit and ornamental trees originating from Southeast Asia have been introduced into Taiwan for planting in residential areas and in the Kentin Tropical Botanical Garden in southern Taiwan (24). It is probable that $P$. noxius was introduced into Taiwan on diseased roots of these exotic tree species.

\section{Symptoms and Development of the Disease}

Brown root rot may occur on trees of all ages. Disease development in most tree species is rapid (8). Foliage on a diseased tree may change from normal color to pale green to brown within 1 or 2 months (Fig. $1)$. This rapid tree death commonly is referred to as quick decline. Some tree species may bloom luxuriantly the year before the onset of quick decline symptoms. For example, flame trees (Delonia regia) nor-

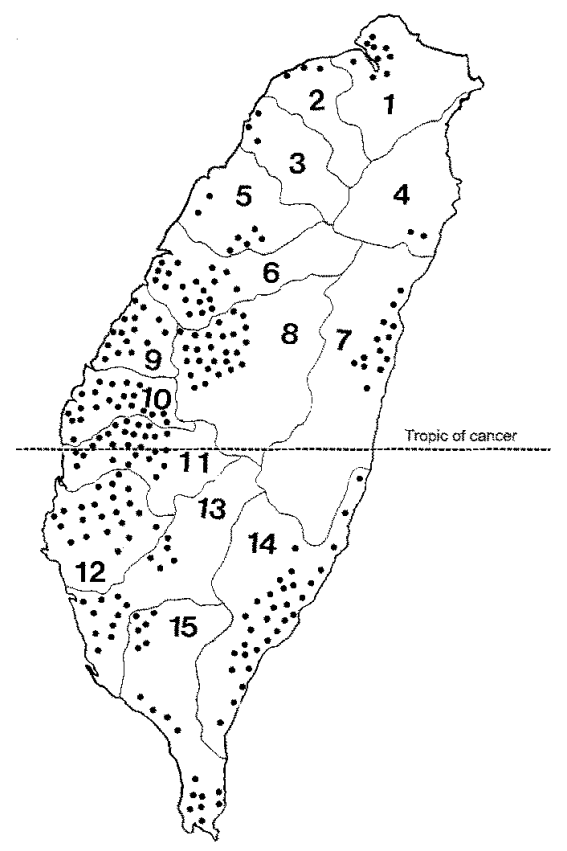

Fig. 10. Geographic distribution of Phellinus noxius in Taiwan. Each point represents a combination of host and locality. Each number represents one of the following counties: 1, Taipei; 2, Tao Yuan; 3, Hsin Chu; 4, I Lan; 5, Miao Li; 6, Taichung; 7, Hua Len; 8, Nan Tow; 9, Chang Hua; 10, Yun Lin; 11, Chia Yi; 12, Tainan; 13, Kaohsiung; 14, Taitung; 15, Pingtung.
Table 1. List of host records of Phellinus noxius in Taiwan

\begin{tabular}{|c|c|c|c|}
\hline Scientific name (common name) & $\begin{array}{l}\text { Year first } \\
\text { reported } \\
\text { (or found) }\end{array}$ & $\begin{array}{c}\text { Reported } \\
\text { (or found) } \\
\text { as new disease }\end{array}$ & Citation \\
\hline \multicolumn{4}{|l|}{ Fruit trees } \\
\hline 1. Annona montana (mountain soursop) & 1996 & $t^{\mathrm{a}}$ & 6,8 \\
\hline 2. Annona squamosa (custard apple) & 1991 & + & $3,7,23$ \\
\hline 3. Annona squamosa $\times$ A. cherimola (atimoya) & (1994) & + & $\mathrm{U}^{\mathrm{b}}$ \\
\hline 4. Artocarpus heterophyllus (jack fruit) & 1998 & + & 17 \\
\hline 5. Averrhoa carambola (carambola) & 1991 & + & 3,7 \\
\hline 6. Dimocarpus longan (longan) & 1928 & + & 4,26 \\
\hline 7. Diospyros kaki (persimmon) & 1994 & + & 5,7 \\
\hline 8. Elaeocarpus serratus (Ceylon olive) & 1998 & + & 17 \\
\hline 9. Eriobotrya japonica (loquat) & 1991 & + & 3,7 \\
\hline 10. Ficus pumila var. awkeotsang (jellyfig) & 1991 & + & 7,23 \\
\hline 11. Litchi chinensis (litchi) & 1991 & + & 3,7 \\
\hline 12. Muntingia calabura (Indian cherry) & (1997) & + & $\mathrm{U}$ \\
\hline 13. Pachira macrocarpa (malabar chestnut) & 1991 & + & 8,23 \\
\hline 14. Persea americana (avocado) & (1988) & - & $\mathrm{U}$ \\
\hline 15. Prunus mите (Japanese apricot, plum) & 1991 & + & $3,7,12$ \\
\hline 16. Prunus persica (peach) & 1999 & + & 8 \\
\hline 17. Pyrus pyrifolia (pear) & 1991 & + & 7,23 \\
\hline 18. Syzygium samarangense (wax apple) & 1992 & + & 4,7 \\
\hline 19. Sterculia nobilis (ping-pong) & 1991 & + & 8,23 \\
\hline 20. Vitis vinifera (grape) & 1996 & + & 6,7 \\
\hline \multicolumn{4}{|l|}{ Ornamental trees } \\
\hline 21. Acacia confusa (Taiwan acacia) & 1995 & - & 14 \\
\hline 22. Actinodaphne pedicellata (litsea) & 1928 & + & 26 \\
\hline 23. Aleurites fordii (tungoil tree) & 1998 & + & 17 \\
\hline 24. Alstonia scholaris (blackboard tree) & 1998 & + & 17 \\
\hline 25. Araucaria cunninghamii (hook pine) & 1998 & - & 17 \\
\hline 26. Araucaria heterophylla (Norfolk Island pine) & 1998 & + & 17 \\
\hline 27. Bauhinia $\times$ hybrid (butterfly-tree) & 1996 & + & 6,8 \\
\hline 28. Bauhinia purpurea (purple bauhinia) & 1996 & + & 6,8 \\
\hline 29. Bauhinia variegata (orchid-tree) & 1942 & + & 17,27 \\
\hline 30. Bischofia javanica (autumn maple tree) & 1928 & + & 17,26 \\
\hline 31. Bombax ceiba (silk cotton) & 1998 & + & 17 \\
\hline $\begin{array}{l}\text { 32. Broussonetia kazinoki (small paper } \\
\text { mulberry) }\end{array}$ & (1998) & + & $\mathrm{U}$ \\
\hline 33. Broussonetia papyrifera (paper mulberry) & (1998) & + & $\mathrm{U}$ \\
\hline $\begin{array}{l}\text { 34. Calocedrus formosana (Taiwan incense } \\
\text { cedar) }\end{array}$ & (1998) & + & $\mathrm{U}$ \\
\hline $\begin{array}{l}\text { 35. Calophyllum inophyllum (Indian poon beauty } \\
\text { leaf) }\end{array}$ & 1995 & - & 17 \\
\hline 36. Camellia japonica (camellia) & 1998 & + & 17 \\
\hline 37. Cassia fistula (yellow golden shower tree) & 1998 & + & 17 \\
\hline 38. Casuarina equisetifolia (ironwood tree) & 1995 & - & 17 \\
\hline 39. Ceiba pentandra & (1998) & - & $\mathrm{U}$ \\
\hline 40. Cerbera manghas (odollam cerberus tree) & (1998) & + & $\mathrm{U}$ \\
\hline $\begin{array}{l}\text { 41. Chamaecyparis formosensis (Taiwan red } \\
\text { cypress) }\end{array}$ & (1998) & + & $\mathrm{U}$ \\
\hline 42. Chorisia speciosa (floss silk tree) & 1999 & - & 8 \\
\hline $\begin{array}{l}\text { 43. Chrysalidocarpus lutescens (yellow areca } \\
\text { palm) }\end{array}$ & $(1999)$ & + & $\mathrm{U}$ \\
\hline 44. Cinnaтотит kanehirai (stout camphor) & 1998 & + & 17 \\
\hline 45. Codiaeum variegatum (croton) & 1928 & - & 26 \\
\hline 46. Cryptocarya concinnai (Konishi crytocarya) & (1998) & + & $\mathrm{U}$ \\
\hline 47. Cycas taiwaniana (Taiwan cycas) & 1991 & + & 12,13 \\
\hline 48. Dalbergia sissoo (sissoo tree) & 1928 & + & 26 \\
\hline 49. Delonix regia (flame tree) & 1991 & - & 12,13 \\
\hline $\begin{array}{l}\text { 50. Diospyros ferrea var. buxifolia (Philippine } \\
\text { ebony persimmon) }\end{array}$ & $(2000)$ & + & $\mathrm{U}$ \\
\hline 51. Diospyros oldhamii (oldham persimmon) & $(2000)$ & + & $\mathrm{U}$ \\
\hline 52. Duranta repens (creeping sky flower) & 1928 & + & 8,26 \\
\hline $\begin{array}{l}\text { 53. Eucalyptus camaldulensis (murray red gum } \\
\text { eucalyptus) }\end{array}$ & 1991 & + & 12,13 \\
\hline $\begin{array}{l}\text { 54. Eucalyptus citriodora (lemon gum } \\
\text { eucalyptus) }\end{array}$ & 1991 & + & 12,13 \\
\hline 55. Eucalyptus grandis (maiden eucalyptus) & 1991 & + & 12,13 \\
\hline 56. Ficus elastica (rubber plant) & 1998 & + & 17 \\
\hline 57. Ficus microcarpa (small-leafed banyan) & 1995 & + & 14 \\
\hline \multirow{2}{*}{ 58. Ficus religiosa (botree fig) } & 1996 & + & 6,8 \\
\hline & & \multicolumn{2}{|c|}{ (continued on next page) } \\
\hline
\end{tabular}

${ }^{\mathrm{a}}+$, first reported (or found) worldwide; -, first report was not from Taiwan.

${ }^{\mathrm{b}} \mathrm{U}$, unpublished. 
Table 1. (continued from preceding page)

\begin{tabular}{|c|c|c|c|}
\hline Scientific name (common name) & $\begin{array}{l}\text { Year first } \\
\text { reported } \\
\text { (or found) }\end{array}$ & $\begin{array}{c}\text { Reported } \\
\text { (or found) } \\
\text { as new disease }\end{array}$ & Citation \\
\hline 59. Firmiana simplex (Chinese parasol) & 1998 & + & 17 \\
\hline 60. Fraxinus formosana (island ash) & 1998 & + & 17 \\
\hline 61. Gardenia jasminoides (cape jasmine) & 1928 & + & 26 \\
\hline 62. Grevillea robusta (silver oak) & 1996 & - & 6,8 \\
\hline 63. Hibiscus rosa-sinensis (hibiscus) & 1996 & - & 6,8 \\
\hline 64. Hibiscus schizopetalus (fringed hibiscus) & 1928 & + & 26 \\
\hline 65. Hibiscus tiliaceus (linden hibiscus) & 1998 & - & 17 \\
\hline 66. Hydrangea chinensis (Chinese hydrangea) & 1928 & + & 26 \\
\hline $\begin{array}{l}\text { 67. Keteleeria davidiana var. formosana } \\
\text { (Taiwan keteleeria) }\end{array}$ & 1998 & + & 17 \\
\hline 68. Kigelia pinnata (sausage tree) & 1999 & + & 8 \\
\hline 69. Koelreuteria henryi (flame gold rain tree) & 1995 & + & 14 \\
\hline 70. Lagerstroemia turbinata (crape myrtle) & 1998 & + & 17 \\
\hline $\begin{array}{l}\text { 71. Lagerstroemia speciosa (queen's crape } \\
\text { myrtle) }\end{array}$ & 1996 & + & 6,8 \\
\hline 72. Lantana camara (lantana) & 1998 & + & 17 \\
\hline 73. Leucaena leucocephala (white popinac) & 1998 & - & 17 \\
\hline 74. Liquidambar formosana (maple) & 1991 & + & 12,17 \\
\hline 75. Litsea glutinosa & 1998 & + & 17 \\
\hline 76. Litsea hypophaea & 1928 & + & 26 \\
\hline 77. Macaranga tanarius (macaranga) & 1998 & + & 17 \\
\hline 78. Machilus zuihoensis (incense machilus) & 1928 & + & 26 \\
\hline 79. Maesa tenera (Taiwan maesa) & 1928 & + & 26 \\
\hline 80. Mallotus paniculatus (turn in the wind) & $(2000)$ & + & $\mathrm{U}$ \\
\hline 81. Melaleuca leucadendron (cajuput tree) & 1996 & + & 6,8 \\
\hline 82. Melia azedarach (China berry) & 1928 & - & 26 \\
\hline $\begin{array}{l}\text { 83. Melodinus angustifolius (narrow leafed } \\
\text { melodinus) }\end{array}$ & (1999) & + & $\mathrm{U}$ \\
\hline 84. Michelia compresa (Formosan michelia) & 1998 & + & 17 \\
\hline 85. Michelia figo (banana magnolia) & 1996 & + & 6,8 \\
\hline 86. Muntingia calabura & (1998) & + & U \\
\hline 87. Murraya paniculata (orange jasmine) & 1928 & + & 13,26 \\
\hline 88. Neolitsea parvigemma (small bud neolitsea) & $(2000)$ & + & U \\
\hline 89. Nerium oleander (oleander) & 1998 & + & 17 \\
\hline 90. Palaquium formosanum (Formosan nato tree) & 1998 & + & 17 \\
\hline 91. Pinus thunbergii (black pine) & 1998 & + & 17 \\
\hline 92. Pistacia chinensis (Chinese pistache) & 1998 & + & 17 \\
\hline 93. Podocarpus macrophyllus & 1995 & - & 14 \\
\hline 94. Pongamia pinnata (pongamia) & 1998 & + & 17 \\
\hline 95. Pterocarpus indicus (rose wood) & 1998 & - & 17 \\
\hline 96. Prunus campanulata (Taiwan cherry) & 1999 & + & 8 \\
\hline 97. Osmanthus fragrans (sweet osmanthus) & $(1998)$ & + & $\mathrm{U}$ \\
\hline 98. Rhododendron obtusum (rhododendron) & (1998) & + & $\mathrm{U}$ \\
\hline 99. Roystonea regia (royal palm) & 1996 & + & 6,8 \\
\hline 100. Salix babylonica (willow) & 1995 & + & 14 \\
\hline 101. Scheffera octophylla (scheffera) & (1999) & + & $\mathrm{U}$ \\
\hline 102. Sterculia foetida (hazel sterculia) & 1999 & + & 8 \\
\hline 103. Swietenia mahagoni (mahogany) & 1995 & + & 14 \\
\hline $\begin{array}{l}\text { 104. Tabebuia chrysantha (yellow golden bell } \\
\text { tree) }\end{array}$ & $(2000)$ & - & $\mathrm{U}$ \\
\hline 105. Taiwania cryptomerioides (Taiwania) & 1998 & + & 17 \\
\hline 106. Terminalia catappa (Indian almond) & 1996 & + & 6,8 \\
\hline 107. Terminalia boivinii & (1998) & + & $\mathrm{U}$ \\
\hline 108. Ulmus parvifolia (Chinese elm) & 1998 & + & 7 \\
\hline 109. Zelkova serrata var. serrat (zelkova) & 1996 & + & 6,8 \\
\hline \multicolumn{4}{|l|}{ Special crops } \\
\hline 110. Camellia sinensis (tea) & 1965 & - & 10 \\
\hline 111. Cinnamomum camphora (camphor) & 1928 & - & 13,26 \\
\hline 112. Cinnamomum zeylanicum (Ceylon cinnamon) & 1998 & + & 17 \\
\hline 113. Coffea arabica (coffee) & 1943 & + & 28 \\
\hline 114. Cordia dichotoma (cordia) & 1998 & + & 17 \\
\hline \multicolumn{4}{|l|}{ Herbaceous plants } \\
\hline 115. Artemisia capillaris (wormwood) & 1998 & + & 17 \\
\hline 116. Artemisia princeps (mugwort) & (1997) & + & $\mathrm{U}$ \\
\hline 117. Ipomoea pescaprae & 1998 & + & 17 \\
\hline 118. Lactuca indica (wild lettuce) & 1998 & + & 17 \\
\hline 119. Melicope merrilli (melicope) & 1998 & + & 17 \\
\hline 120. Sauranja oldhami & 1928 & + & 26 \\
\hline 121. Urena lobata (cadillo) & 1928 & + & 26 \\
\hline
\end{tabular}

mally bloom sparingly in central Taiwan. However, flame trees with incipient infections often flower profusely in the year preceding quick decline (Fig. 11A and B). Because infection originates from the roots near the basal stem, a large portion of the trunk may have already been invaded by the pathogen before the appearance of decline symptoms. This may reduce the amount of water passing through the trunk to a level insufficient to support the whole tree, thereby triggering the development of flower buds and then the onset of quick decline (20).

Decline symptoms in other trees may occur over periods of a year or more (8) (Fig. 12). This slow decline may be the result of root infections originating at greater distances from the trunk. This progressive root destruction impairs carbohydrate storage and water uptake and results in a more gradual defoliation (21). Host resistance and vigor, and pathogen isolates that are relatively nonaggressive, may also contribute to the slow process of disease development. When greater destruction of the root system by $P$. noxius occurs on one side of the root system, the affected tree may display yellowing and defoliation only on that side of the crown during the early stages of disease development.

Roots infected with $P$. noxius initially exhibit a brown discoloration of the wood just beneath the bark (Fig. 2). In advanced stages of decay, the wood develops a soft, stringy white rot with a conspicuous network of brown zone lines (Fig. 13). The outer bark surface appears rough because it is covered with a layer of adhering soil particles and brown fungal mycelia (Fig. 14). The inner bark is covered with the white to brownish mycelial mat (Fig. 15).

Occasionally, thin, hard and flat basidiocarps are formed on the basal trunks or exposed roots of diseased trees. The conks are initially white with the context gradually turning yellow to brown (Fig. 16). The conks eventually become brownish-gray or dark gray (Fig. 17).

\section{Dissemination and Survival of the Pathogen}

The way by which new infection centers of brown root rot are established is still undetermined. It is likely that $P$. noxius is introduced into new areas on trees infected in the nursery and then planted in the landscape. The fungus may then spread to adjacent trees through root-to-root contact $(7,11)$ (Fig. 18). A brown root rot infection center also may arise following colonization of a freshly cut stump by basidiospores (11) (Fig. 18) and then mycelial movement from the stump to surrounding healthy roots. However, this probably is not a common method by which $P$. noxius initiates new disease centers in Taiwan because the fungus rarely produces basidiocarps on diseased trees in the field $(8,13,14)$. Arthrospores produced by $P$. 

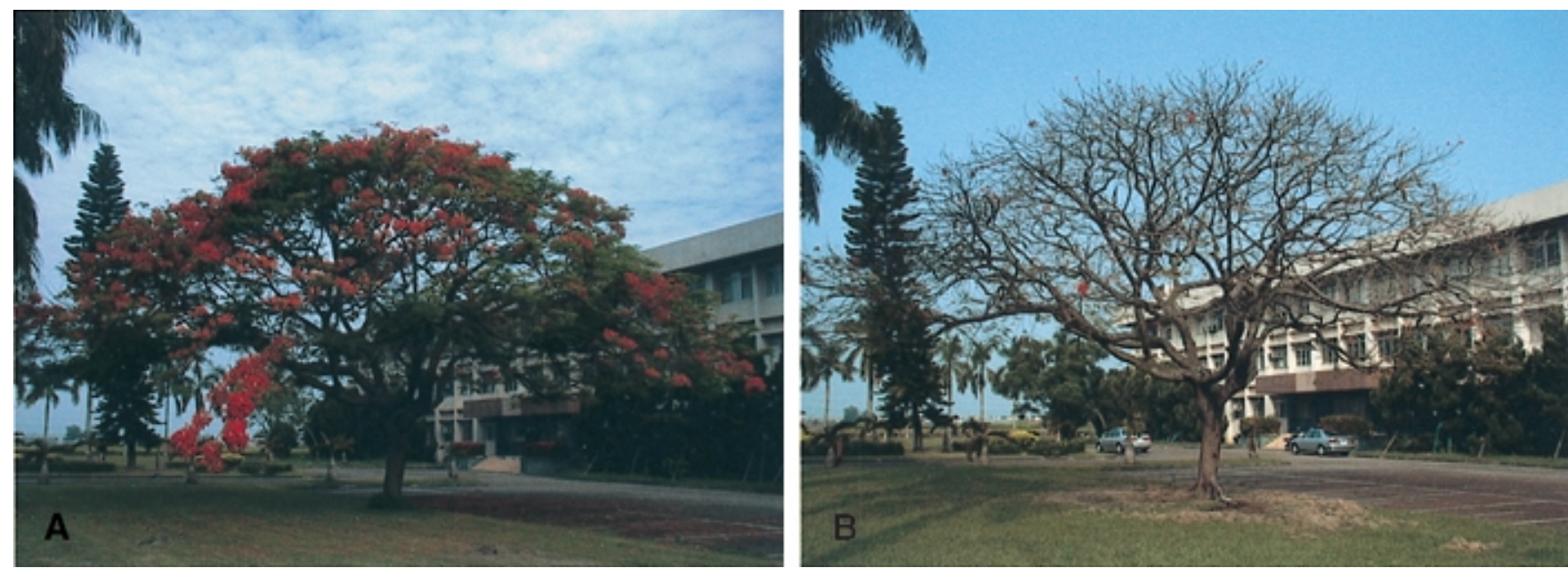

Fig. 11. A 30-year-old flame tree (Delonia regia) in central Taiwan. A, 3 months before the appearance of quick decline; B, after the appearance of quick decline. (courtesy H. Y. Lu)

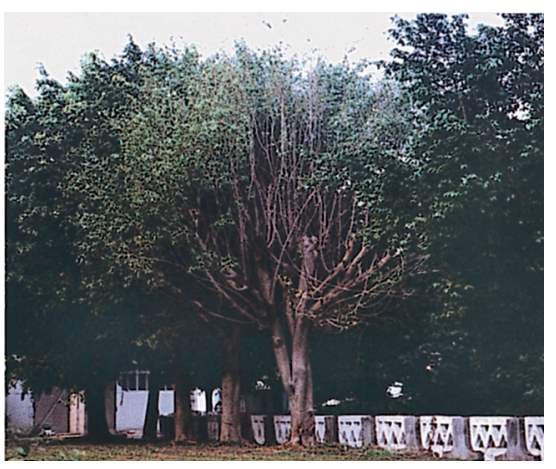

Fig. 12. Slow decline of a 20-year-old small-leafed banyan tree (Ficus microcarpa) resulting from Phellinus noxius brown root rot.

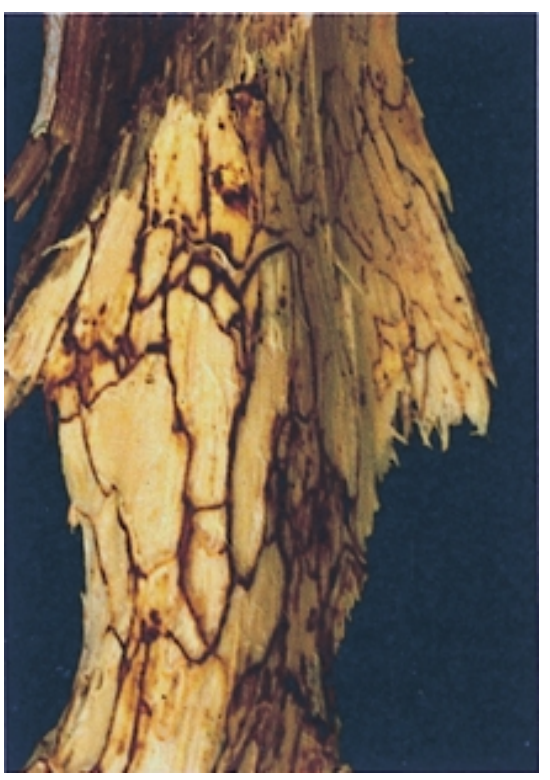

Fig. 13. A longan root (Dimocarpus longan) showing advanced white rot symptoms caused by Phellinus noxius. Note the conspicuous network of brown lines permeating the white and soft wood tissue.

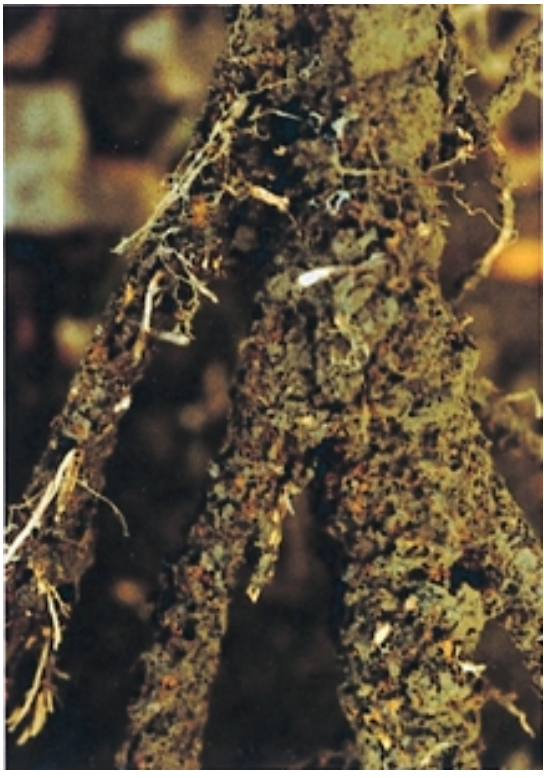

Fig. 14. Outer surface of diseased Iongan roots (Dimocarpus longan) covered with a layer of adhering mixture of soil particles and brownish fungal mycelia of Phellinus noxius.

noxius in culture are probably not an important source of inoculum in nature because they have never been observed in the field (11).

After tree removal, $P$. noxius can survive in colonized roots remaining in the soil for more than 10 years (15). It can also remain viable as mycelium in the rhizosphere for several months.

\section{Measures for Disease Control}

Replanting of susceptible trees in infested soils is not recommended because they may become infected after contact with mycelium in the rhizosphere or in buried roots (2) (Fig. 18). Many soil treatments have been tested and numerous experiments have been performed to find an effective way of eliminating such inocu-

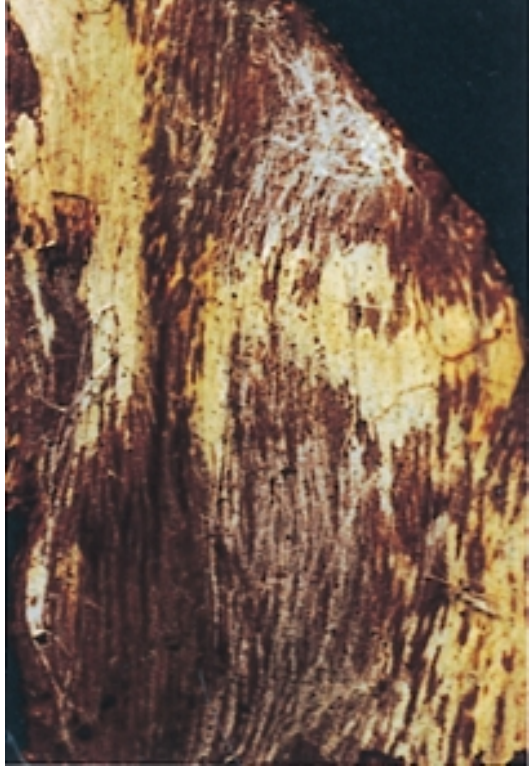

Fig. 15. Inner surface of bark of diseased longan root (Dimocarpus longan) covered with a white to brown mycelial mat of Phellinus noxius.

lum. Currently, the most efficient method of destroying the residual inoculum is by flooding the field (15), and the most practical way is to fumigate the infested soil with ammonia generated from urea amended in soil under alkaline conditions $(5,16)$. Another approach is to replant the infested areas with resistant species (9).

The recommended replacement species for fruit trees are mango and citrus. For ornamental trees, the locally popular species of Alstonia scholaris is recommended. Although A. scholaris is listed in Table 1 as a host, inoculation tests show that it is very resistant to P. noxius (9).

\section{Current Status and Future Outlook}

Besides Taiwan, $P$. noxius is widespread in other parts of Southeast Asia and the 
South Pacific (25). Brown root rot may become a serious problem in these regions if a large number of susceptible fruit and ornamental trees were planted in infested areas, or if tree seedlings from infested nurseries were used for agricultural and landscape plantings. Since $P$. noxius attacks a wide range of plant species, more

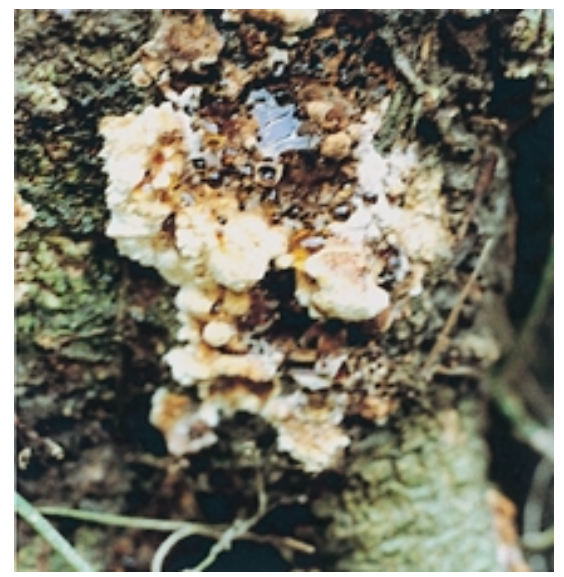

Fig. 16. Young fruiting bodies of Phellinus noxius produced on a declining longan tree (Dimocarpus longan). reports concerning the incidence of brown root rot may be expected in these regions in the future.

More information regarding the use of fungicides is needed to slow down and hopefully stop disease development in infected trees next to a dying or dead tree.

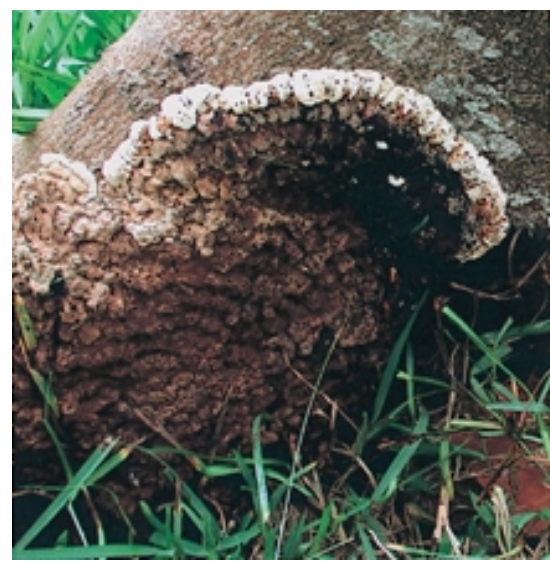

Fig. 17. Mature fruiting bodies of Phellinus noxius produced on a declining flame tree (Delonia regia). (courtesy $\mathrm{J}$. H. Huang)
In this regard, seven of 45 fungicides have been found to be strongly inhibitory to the growth of $P$. noxius in vitro (5). These fungicides were further evaluated for their ability to control the disease in greenhouse experiments. The systemic fungicides triadimefon, prochloraz, and mepronil were found to be nonphytotoxic and effective in reducing disease incidence.

Recently, each of these fungicides was applied to diseased grapevines in the field as a soil drench once every 3 months in combination with a soil amendment containing lime and urea. The treatments appear to be promising, as no further decline or death of grapevines was recorded in the treated plots, while disease progress remained unchecked in the control plot. Thus, it appears likely that fungicides can be useful in managing disease development. Still to be determined is the recurrent rate of brown root rot after the termination of the treatments and the economic feasibility of the treatments.

There is a wide range of susceptibility to brown root rot among different species of the same genus, and among different varieties of the same species (9). Disease resistance needs to be further identified and

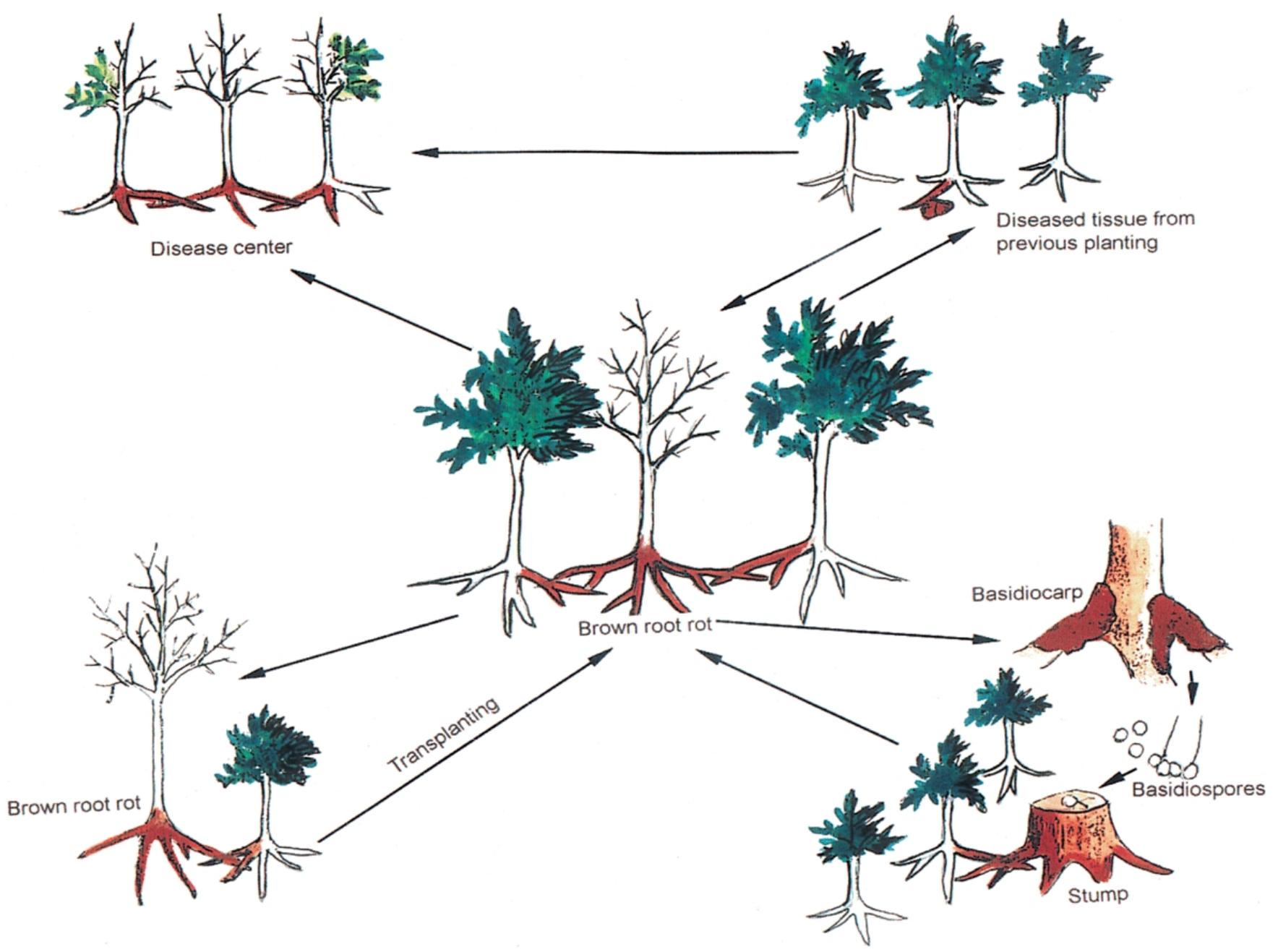

Fig. 18. Diagrammatic illustration of the disease cycle of Phellinus noxius brown root rot on susceptible trees. 
characterized as a basis for development of commercially acceptable resistant fruit and ornamental trees through conventional breeding and genetic engineering.

\section{Acknowledgments}

We thank H. Y. Lu and J. H. Huang for supplying pictures used in Figures 11 and 17, respectively, and C. Y. Wong for assistance in checking the scientific names of host plants. This research was supported, in part, by grants from the Agricultural Council of Taiwan, and National Science Council grant NSC87-2313-B-054-009 from Taiwan. This is contribution 2084 from the Taiwan Agricultural Research Institute.

\section{Literature Cited}

1. Abe, Y., Kobayashi, T., Onuki, M., Hattori, T., and Tsurumachi, M. 1995. Brown root rot of trees caused by Phellinus noxius in windbreaks on Ishigaki Island, Japan - Incidence of disease, pathogen and artificial inoculation. Ann. Phytopathol. Soc. Jpn. 61:425-433.

2. Ann, P. J., and Ko, W. H. 1991. Association of Phellinus noxius with decline of longan (Euphoria longan) trees. (Abstr.) Phytopathology 81:1232.

3. Ann, P. J., and Ko, W. H. 1991. Association of Phellinus noxius with root rot of fruit trees in Taiwan. (Abstr.) Plant Prot. Bull. (Taiwan) 33:432-433.

4. Ann, P. J., and Ko, W. H. 1992. Decline of longan trees: Association with brown root rot caused by Phellinus noxius. Plant Pathol. Bull. (Taiwan) 1:19-25.

5. Ann, P. J., and Ko, W. H. 1994. Studies on ecology of brown root rot of fruit trees caused by Phellinus noxius and disease control. (Abstr.) Plant Pathol. Bull. (Taiwan) 3:69.

6. Ann, P. J., Lee, H. L., and Huang, T. C. 1996.
New host records of Phellinus noxius causing brown root rot of fruit and ornamental trees in Taiwan and response of horticultural plants to the pathogen via artificial inoculation. (Abstr.) Plant Pathol. Bull. (Taiwan) 5:201.

7. Ann, P. J., Lee, H. L., and Huang, T. C. 1999. Brown root rot of 10 species of fruit trees caused by Phellinus noxius in Taiwan. Plant Dis. 83:746-750.

8. Ann, P. J., Lee, H. L., and Tsai, J. N. 1999. Survey of brown root disease of fruit and ornamental trees caused by Phellinus noxius in Taiwan. Plant Pathol. Bull. (Taiwan) 8:51-60.

9. Ann, P. J., Tsai, J. N., Wang, I. T., and Hsieh, M. J. 1999. Response of fruit trees and ornamental plants to brown root rot disease by artificial inoculation with Phellinus noxius. Plant Pathol. Bull. (Taiwan) 8:61-66.

10. Anonymous. 1995. Tea brown root disease and longan brown root disease. Agric. Rev. (Taiwan) 4:141, 255.

11. Bolland, L. 1984. Phellinus noxius: Cause of a significant root rot in Queensland hoop pine plantations. Aust. For. 47:2-10.

12. Chang, T. T. 1991. Phellinus noxius causing root rot and collar rot of several tree species in Taiwan. (Abstr.) Plant Prot. Bull. (Taiwan) 33:432.

13. Chang, T. T. 1992. Decline of some forest trees associated with brown root rot caused by Phellinus noxius. Plant Pathol. Bull. (Taiwan) 1:90-95

14. Chang, T. T. 1995. Decline of nine tree species associated with brown root rot caused by Phellinus noxius in Taiwan. Plant Dis. 79:962-965.

15. Chang, T. T. 1996. Survival of Phellinus noxius in soil and in the roots of dead host plants. Phytopathology 86:272-276.

16. Chang, T. T., and Chang, R. J. 1999. Generation of volatile ammonia from urea fungicidal to Phellinus noxius in infested wood in soil under controlled conditions. Plant Pathol. 48:337-344.

17. Chang, T. T., and Yang, W. W. 1998. Phellinus noxius in Taiwan: Distribution, host plants and the $\mathrm{pH}$ and texture of the rhizosphere soils of infected hosts. Mycol. Res. 102:1085-1088.

18. Corner, E. J. H. 1932. The identification of the brown root fungus. Gard. Bull. Straits Settl. 5:317-350.

19. Cunningham, G. H. 1965. Polyporaceae of New Zealand. N.Z. Dep. Sci. Indust. Res. Bull. 164:221-222.

20. Ko, W. H., and Kunimoto, R. K. 1996. Quick decline of macadamia trees: Association with Phellinus gilvus. Ann. Phytopathol. Soc. Jpn. 62:37-39.

21. Ko, W. H., Kunimoto, R. K., and Maedo, I. 1977. Root decay caused by Kretzschmaria clavus: Its relation to macadamia decline. Phytopathology 67:18-21.

22. Ko, W. H., Tomita, J., and Short, R. L. 1986. Two natural hosts of Kretzschmaria clavus in Hawaiian forests. Plant Pathol. 35:254-255.

23. Lee, H. L., and Huang, T. C. 1991. Preliminary studies on wilt disease of custard apple. (Abstr.) Plant Prot. Bull. (Taiwan) 33:433.

24. Liu, T. R., Wang, J. L., and Liao, R. J. 1967. Exotic plant species in Taiwan. Taiwan For Bull. 3:114-167.

25. Pegler, D. N., and Waterston, J. M. 1968 Phellinus noxius. No. 195 in: Descriptions of Pathogenic Fungi and Bacteria. Commonw. Mycol. Inst., Kew, England.

26. Sawada, K. 1928. Camphor tree decline. Descript. Catal. Formosan Fungi 4:86-91.

27. Sawada, K. 1942. Bauhinia decline. Descript. Catal. Formosan Fungi 7:97-98.

28. Sawada, K. 1943. Coffee decline. Descript Catal. Formosan Fungi 8:149-150.

29. Tai, F. L. 1979. Sylloge Fungorum Sinicorum Science Press, Academia Sinica, Peking, China.

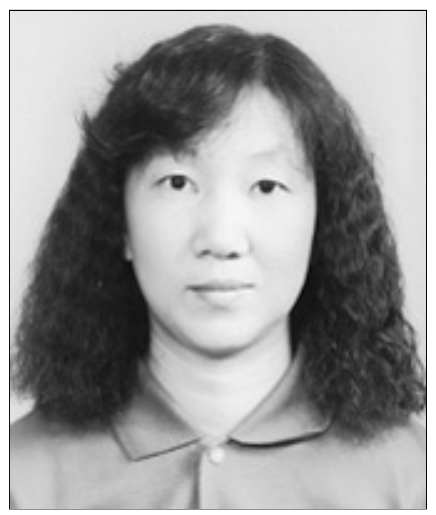

Pao-Jen Ann

Dr. Ann is a senior researcher of the Department of Plant Pathology, Taiwan Agricultural Research Institute, Taichung, Taiwan. She received her B.S. and M.S. degrees from National Taiwan University at Taipei, Taiwan, and her Ph.D. degree from the University of Hawaii. Her current research interests include fungal diseases of fruit trees and etiology and control of diseases caused by species of Phytophthora. She received the Agricultural Research and Development Award from the Department of Agriculture and Forestry of Taiwan in 1997.

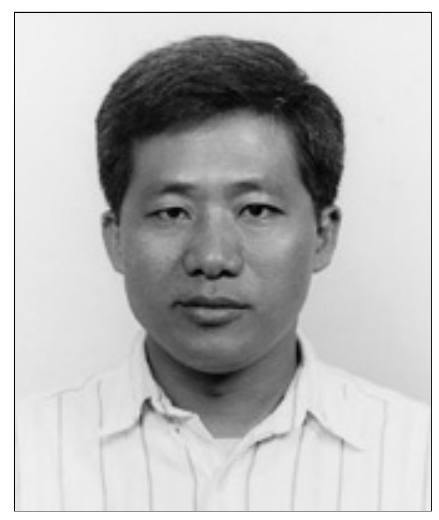

Tun-Tschu Chang

Dr. Chang is a principal scientist and head of the Forest Protection Division of Taiwan Forestry Research Institute, Taipei, Taiwan. He received B.S. and M.S. degrees from National Taiwan University at Taipei, Taiwan, and his Ph.D. degree from the University of Hawaii. His current research focuses on root diseases of woody trees caused by Basidiomycetes and taxonomy of woodinhabiting Aphyllophorales. He received the Outstanding Research Award from the National Science Council of Taiwan in 1996.

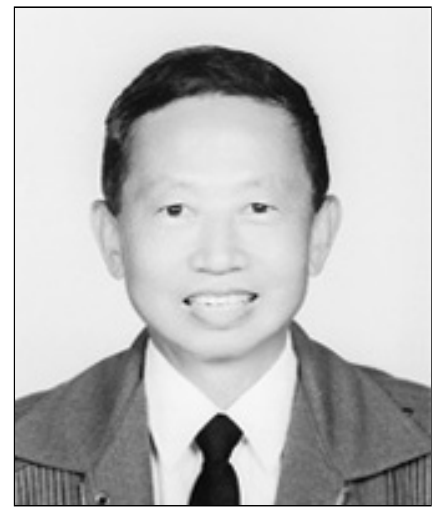

\section{Wen-Hsiung Ko}

Dr. Ko is professor of plant pathology at Beaumont Agricultural Research Center of the University of Hawaii. He received his B.S. degree from National Taiwan University and his Ph.D. degree from Michigan State University. His research interests include ecology and biological control of soilborne diseases of tropical fruit crops and biology of Phytophthora. $\mathrm{He}$ received the Ruth Allen Award in 1984 from the American Phytopathological Society for his contribution in hormonal regulation of sexual reproduction in Phytophthora and is a Fellow of the American Phytopathological Society. 